\title{
Changes in inflorescence protein during advanced stages of floret development in Buchloe dactyloides (Poaceae)
}

\author{
Y.-J. Zhou ${ }^{1,2 *}$, J.-G. Xue ${ }^{1 *}$, X.-G. Wang ${ }^{1}$ and X.-Q. Zhang ${ }^{2}$ \\ ${ }^{1}$ Department of Grassland Science, China Agricultural University, \\ Beijing, China \\ ${ }^{2}$ Department of Grassland Science, Sichuan Agricultural University, \\ Yaan, China \\ *These authors contributed equally to this study. \\ Corresponding author: X.-G. Wang \\ E-mail: grasschina@126.com
}

Genet. Mol. Res. 11 (4): 3923-3932 (2012)

Received October 13, 2011

Accepted February 27, 2012

Published August 17, 2012

DOI http://dx.doi.org/10.4238/2012.August.17.5

\begin{abstract}
Buffalograss, Buchloe dactyloides, is a dioecious species native to the Great Plains of North America. The florets at the early stages of development possess both gynoecium and androecium organ primordia but later become unisexual. Very little is known about the proteomic changes that occur when the florets change from hermaphroditism to unisexuality. We compared the protein composition of florets at the hermaphroditic stage with that at the unisexual stage. The development stage of the floret was determined by stereomicroscopic observation. Two-dimensional gel electrophoresis was used to separate the proteins extracted from female and male inflorescences. Stagespecific protein maps, with an average of about 400 spots per map, were analyzed with the protein analysis software. Eighteen spots were found to be differentially expressed between the hermaphrodite and unisexual stages. Of these, 12 were present at both stages but with a different expression value. Four specific spots appeared at the hermaphrodite
\end{abstract}


stage and disappeared at the unisexual stage. Two specific protein spots were associated with female and male floret differentiation. One appears to be associated with contabescence in the female floret and the final protein appears to lead to the abortion of gynoecium in the male floret. The MALDI TOF/TOF technique was used for peptide mass fingerprinting of the differentially expressed proteins and the MASCOT software was used to search the protein database. However, only two protein spots were identified from the database. These were aldolase 1 and Os05g0574400 (similar to malate dehydrogenase). This type of proteomic study can help to identify novel protein products and determine the mechanisms involved in the floral sex differentiation process in buffalo grass.

Key words: Buchloe dactyloides; Sex differentiation; Floret; Proteome; Inflorescence

\section{INTRODUCTION}

Since its naturalization, buffalograss, Buchloe dactyloides (Nutt.) Engelm, a dioecious species native to North America (Beetle, 1950; Huff and Wu, 1987; Budak, 2004), has become the most widely cultivated warm-season grass in Northern China. Buffalograss produces female and male flowers, which are produced on separate unisexual individuals (Zhou et al., 2011). Furthermore, the inflorescences and spikelets are also sexually dimorphic, which is similar to the female and male plants of Bouteloua dimorpha (Kinney et al., 2008).

Generally, unisexual flowers have been broadly categorized into 2 main types - type I and type II. Most unisexual flowers are categorized into type I, where female and male flowers have aborted, but recognizable, organs of the opposite sex; type II flowers, on the other hand, show no evidence of aborted sex organs (Mitchell and Diggle, 2005). The vegetative features of female and male buffalograss plants are similar and cannot be distinguished on the basis of morphology. Chandra and Huff (2010) described the development of unisexual florets in buffalograss by using a scanning electron microscope. The florets possess both gynoecium and androecium organ primordia at the early stages of development and meet the criteria of type I flowers. The critical time point for sex differentiation is when the floral primordia reach the gynoecial ridge stage. At this point, under the action of male and female suppressor factors, the development of the pistil stops in male florets, while that of the stamen stops in female florets. The floret differentiation in buffalograss is similar to that of maize (Irish and Nelson, 1993).

Plant sex differentiation is a tightly regulated and complicated process, involving certain macromolecular markers, such as protein, tRNA, and mRNA. The process is accompanied by the appearance or disappearance of some sex-linked proteins, which play an important role in flower differentiation. Jindal and Singh (1976) found that specific proteins emerge or disappear in dioecious Carica papaya during the development of staminate and pistillate flowers. Subsequently, some proteins, unique to unisexual flower development, were identified and purified in Asparagus officinalis (Bracale et al., 1990), Pistacia vera (Golan-Goldhirsh et al., 1998), Momordica charantia (Wang and Zeng, 1998), and Gymnocladus dioicus (Hou, 2005). Nevertheless, research on this subject is still at an early stage. For decades, very little was known about 
global protein changes occurring during unisexual flower development because of constraints in sampling technique and poor operating precision. In recent years, two-dimensional (2-D) gel electrophoresis has been widely utilized to separate many complex proteins (at least one hundred to many thousands of proteins) because of its reliability and sensitivity (O'Farrell, 1975; Rossignol, 2004; Farley and Link, 2009). Improvements in mass spectrometry (MS) have made this technique a powerful tool in the characterization of proteins in terms of molecular weight and identifying the structure of intact peptides (Yergey et al., 2002). Proteomics, combined with 2-D gel electrophoresis techniques, mass spectrometry, and the continuously improving comparison databases, have been used in the analysis of specific proteins involved in many complex biochemical processes (Zivy and de Vienne, 2000; van Wijk, 2001).

Almost nothing is known about global protein changes occurring during unisexual flower development. Moreover, fundamental scientific knowledge of buffalograss still lags far behind that of other plants, e.g., maize, alfalfa, wheat, and rice (Imin et al., 2001; Andon et al., 2002; Campo et al., 2004; Incamps et al., 2005). Therefore, the objective of this study was to utilize a proteomic approach (isoelectric focusing/sodium dodecyl sulfate-polyacrylamide gel electrophoresis [IEF/SDS-PAGE] and matrix-assisted laser-desorption time-of-flight [MALDI-TOF/TOF]) to evaluate changes in protein expressions during the sex determination stages of buffalograss floret development. In the present study, stage-specific floret protein patterns were observed, and the major differences between female and male floret development process are described.

\section{MATERIAL AND METHODS}

\section{Plant material}

Female and male buffalograss plants, with very similar genetic backgrounds, were obtained from the USA and grown in an open field at a farm near China Agricultural University. Unisexual floret development was divided into 2 stages on the basis of morphology, as described by Chandra and Huff (2010). At stage 1, florets are hermaphroditic containing both gynoecium and androecium organ primordia, but have reached the ridge stage. Stage 2 is the sex determination stage, wherein stamineal male-suppressor factors lead to the arrest of the androecium in female florets, while male-suppressor factors cause the degeneration of the gynoecium in male florets. The developmental stages of florets were observed using SMZ1500 stereo microscope (Nikon, Japan).

\section{Total protein extraction}

Total protein was extracted according to a modified protocol used by Dafny-Yelin et al. (2005). Samples of inflorescence tissue (200 mg) taken at the 2 stages of floret development were ground to a fine powder in the presence of liquid nitrogen and homogenized at $4^{\circ} \mathrm{C}$ in 1 $\mathrm{mL}$ of an extraction buffer containing $30 \mathrm{mM}$ Tris-HCl, $\mathrm{pH}$ 8.0, $0.1 \mathrm{mM}$ EDTA, $700 \mathrm{mM}$ sucrose, $2 \mathrm{mM}$ phenylmethylsulfonyl fluoride, and $1 \%(\mathrm{v} / \mathrm{v}) \beta$-mercaptoethanol, supplemented with a protease inhibitor cocktail (Roche, Mannheim, Germany). An equal volume of $0.1 \mathrm{M}$ ammonium acetate in methanol was added, and the mixture was stored at $-20^{\circ} \mathrm{C}$ for at least 4 $\mathrm{h}$. The mixture was then centrifuged at $15,000 \mathrm{~g}$ for $15 \mathrm{~min}$. The resulting pellet was rinsed 3 times with cold ammonium acetate in methanol and once with $80 \%$ cold acetone. The vacuum 
pellet was resuspended in $0.5 \mathrm{~mL}$ rehydration buffer containing $8 \mathrm{M}$ urea, $2 \%(w / v)$ CHAPS, $100 \mathrm{mM}$ dithiothreitol (DTT), and $0.5 \%$ (v/v) immobilized $\mathrm{pH}$ gradient (IPG) buffer [pH $=$ 3-10 nonlinear; Amersham Biosciences Biotech, Sweden]. Total protein concentrations were quantified using a PlusOne 2-D Quant kit (GE Healthcare, USA).

\section{2-D gel electrophoresis and gel analysis}

For each sample, $100 \mu \mathrm{g}$ soluble proteins was first separated by IEF. IEF was then carried out using an IPGphor instrument (Amersham Biosciences Biotech). IPG strips (24 cm; pH 3-10 non-linear; Amersham Biosciences Biotech) together with the protein samples were rehydrated using the IPGphor system for $13 \mathrm{~h}$ at $20^{\circ} \mathrm{C}$. IEF was completed using the following protocol: $500 \mathrm{~V}$ for $30 \mathrm{~min}$; $1000 \mathrm{~V}$ for $30 \mathrm{~min} ; 3000 \mathrm{~V}$ for $30 \mathrm{~min}$, and $80,000 \mathrm{~V}$ for $4 \mathrm{~h}$. For 2-D SDS-PAGE, the IPG strips were equilibrated at room temperature in a buffer containing $500 \mathrm{mM}$ Tris-HCl, pH 8.8, $6 \mathrm{M}$ urea, 30\% (v/v) glycerol, 5\% (w/v) SDS, 2\% (w/v) DTT and $1 \%$ bromophenol blue for $15 \mathrm{~min}$. Proteins were then separated in vertical $12 \%$ SDS-PAGE according to Gallardo et al. (2002).

After electrophoresis, the gels were stained using Coomassie brilliant blue (CBB) G-250 according to the method put forth by Mathesius et al. (2001) and by using the silver method described by Blum et al. (1987). Gels stained with CBB and silver were both scanned using a UMAX powerlook 2100XL (Pharmacia) scanner with a resolution of 600 microns/ pixe. The scanned images were analyzed by the PdQuest v. 8.0 software (Bio-Rad, USA) for background subtraction, spot detection, and volume quantification. Differentially expressed spots (at least a 5-fold difference in intensity with non-overlapping errors) were labeled for each floret developmental stage. All values shown were averages taken from 3 technical replicates.

\section{Protein identification}

Protein spots of interest were manually excised with a clean razor blade from CBBstained gels and digested in Trypsin (Promega, Madison, WI, USA) according to a modified procedure previously described by de Jong et al. (2007). The gel slices were rinsed 3 times with 100 $\mu \mathrm{L} 50 \%(\mathrm{v} / \mathrm{v})$ acetonitrile in $25 \mathrm{mM}$ ammonium bicarbonate, dehydrated with $100 \mu \mathrm{L} 100 \%$ acetonitrile, and then dried by vacuum centrifugation. The dried spots were incubated overnight at $37^{\circ} \mathrm{C}$ with Trypsin $(15 \mathrm{ng} / \mu \mathrm{L}$ in $25 \mathrm{mM}$ ammonium bicarbonate). The peptides were desalinated, concentrated under centrifugation, and then resuspended in 50\% acetonitrile containing $1 \%$ formic acid.

Mass spectrometry was performed using a MALDI-TOF/TOF (4800 MALDI-TOF/ TOF) analyzer (Applied Biosystems, UK). Spectra were recorded in the positive reflector mode at an accelerating potential of $20,000 \mathrm{kV}$; ionization was recorded with a nitrogen laser at $355 \mathrm{~nm}$, by using a delayed extraction time of $130 \mathrm{~ns}$, and the output signal digitalized at rates of $200 \mathrm{~Hz}$. Peptides were selected in the mass range between 700 and $4000 \mathrm{Da}$. Mass spectrum database searches, including MSDB, NCBI, and Swissport databases, were undertaken using the MASCOT 2.1.0 software (Matrix-Science). All searches used the following parameters: a maximum of one miss-cleavage, a peptide tolerance of $10 \mathrm{ppm}$, allowance of oxidation (M) modifications, a peptide charge of $1^{+}$, and an MS/MS tolerance of 0.2 Da. 


\section{RESULTS AND DISCUSSION}

The process of unisexual floret differentiation in buffalograss was chosen as a model system for studying the protein patterns of sex organ differentiation in plants. Observation under a stereo-microscope showed that floral development in buffalograss is a complex process involving inflorescence and floret differentiation. At an early stage of development, the pistillate inflorescence primordia are morphologically distinct from their staminate counterparts. Pistillate primordial crowed into a dense cluster, while staminate inflorescence primordia have distinct primary branches, each with 2 or 3 alternating rows of spikelets (Figure 1). In a previous investigation, Chandra and Huff (2010) demonstrated the developmental stages of buffalograss unisexual florets. As the inflorescence branch develops, components of the spikelet and floret are initiated, and gynoecium and androecium primordia become apparent. Until the gynoecial ridge stage, floret primordia are still hermaphroditic, with both pistils and stamens being present. After this stage, however, in the female florets, the stamens stop growing and the pistils continue to develop, while in the male florets, pistils degenerate and develop to maturity.

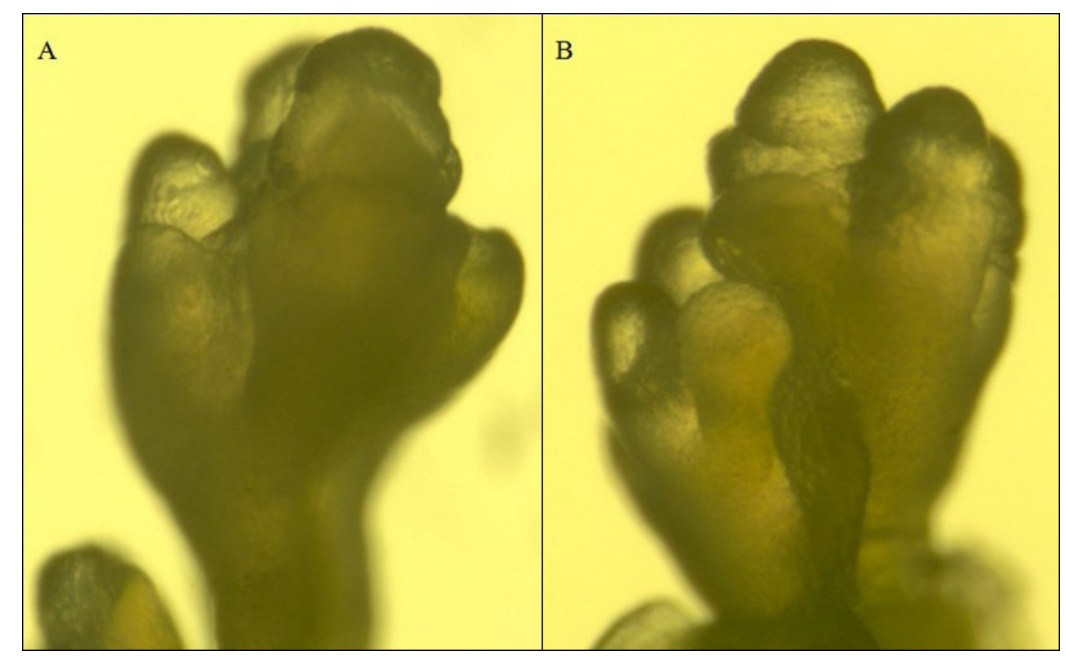

Figure 1. Pistillate (A) and staminate (B) inflorescence primordia under the stereo microscope.

On the basis of stereo-microscopic analysis, the total protein extracted from the male and female inflorescences at the 2 different developmental stages was separated by 2-D PAGE. The gels were stained by silver for gel analysis and with CCB, for MS analysis. To verify the results, the procedure was repeated 3 times, and each set of results was compared. The controls revealed a very high degree of reproducibility. More than 400 prominent protein spots were resolved in an isoelectric point (pI) range of 5-8 and a molecular mass range of 97.2 to 14.3 $\mathrm{kDa}$ on average for each gel. Representative gels (Figure 2) show the protein spots of female and male florets as they progress from the hermaphroditic state to a unisexual state. The main 2-D electrophoresis patterns of the 2 sexes were similar during the floret development process; however, in the case of both female and male flowers, the spots extracted at stage 1 had a higher staining intensity than those extracted at stage 2 , and most spots were stronger than 
those extracted from flowers at stage 2. A comparison of the gels revealed 291 protein spots expressed differentially between the 2 stages (at least a 5 -fold difference). The protein spots extracted from inflorescences and separated by 2-D PAGE were counted (Table 1).

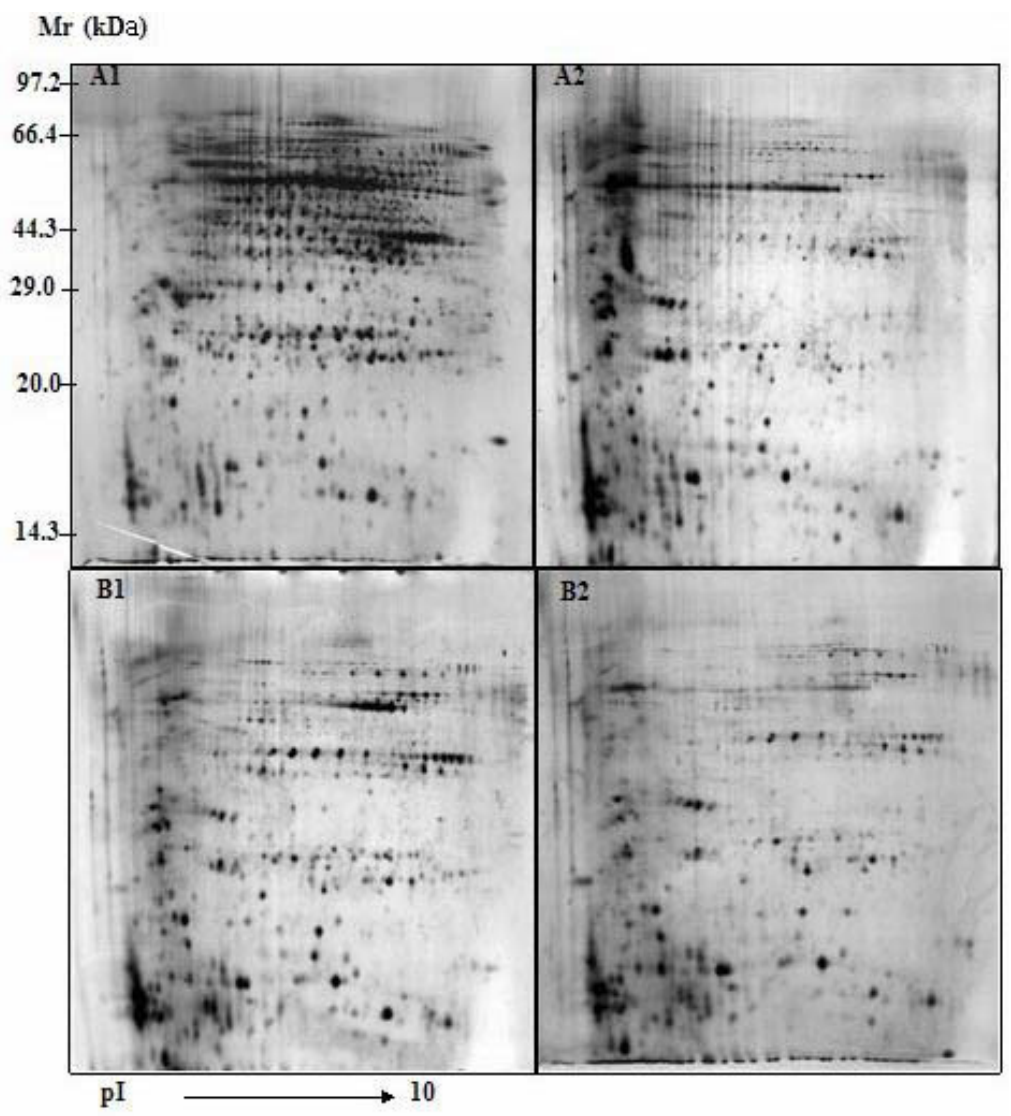

Stage 1

Stage 2

Figure 2. Two-dimensional gel electrophoresis pattern of pistillate $(\mathbf{A})$ and staminate $(\mathbf{B})$ inflorescences when florets develop from the hermaphrodite stage (Stage 1) to unisexuality (Stage 2). $\mathrm{Mr}=$ molecular mass; $\mathrm{pI}=$ isoelectric point.

Table 1. Distribution of buffalograss inflorescence protein spots during floret development.

\begin{tabular}{lcc}
\hline Developmental stage of inflorescence & Protein spots (No.) & Differentially expressed proteins (No.) \\
\hline Female 1 & 547 & \\
Female 2 & 379 & \\
Male 1 & 472 & 206 \\
Male 2 1 compared to female 2 & 325 & 112 \\
Female 1 & 189 \\
Male 1 compared to male 2 & & 211 \\
Female 1 compared to male 1 & & \\
Female 2 compared to male 2 & & \\
\hline
\end{tabular}

Female 1 = floret primordia in female inflorescences at the hermaphrodite stage. Female $2=$ the floret stamens stop growing and the pistillates continue to develop in the female inflorescences, and vice versa. 
Protein spots differentially expressed during the sexual differentiation stage were divided into 4 categories. In type I protein spots, the majority were expressed in both the inflorescences, but at different levels; 12 of them (spots 1-12) were identical in both inflorescences at the hermaphroditic stage, but quite different at the unisexual stage. Four spots (spots 13-16) that were present in hermaphrodite florets, but absent in unisexual florets were categorized as type II. Spot 17, which was present in male unisex florets but absent or drastically reduced in intensity in female florets, was classified as type III. This protein might play a significant role in the abortion of the gynoecium in male florets. Another protein spot (spot 18) that was only present in female unisex florets was classified as type IV. This protein is expected to play an important role in promoting contabescence in female florets. A total of 18 protein spots appeared to exhibit a close association between their expression and floret development. The sex-linked spots have been indicated by numbers in Figure 3. Proteins identified by MALDITOF/TOF analyses were annotated on a master gel (Figure 4). Among the annotated proteins, 2 spots were directly characterized from their peptide mass fingerprints with a putative function (Table 2). The majority of sex-linked protein spots could not be identified by MS.

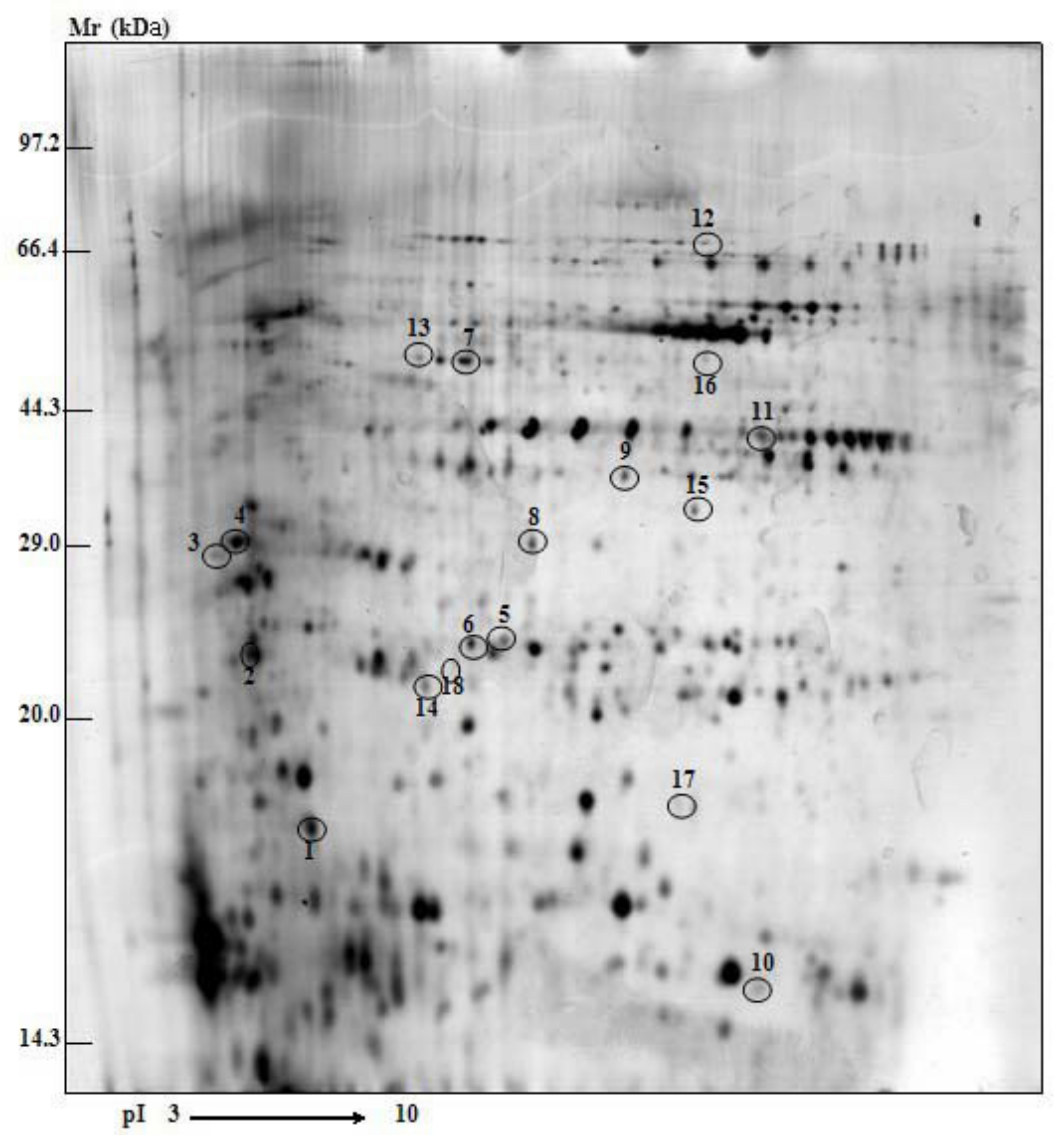

Figure 3. Proteins identified by matrix-assisted laser-desorption time-of-flight. The coded spots were shown on patterns of proteins from the Male 1 stage. For abbreviations, see Figure 2. 

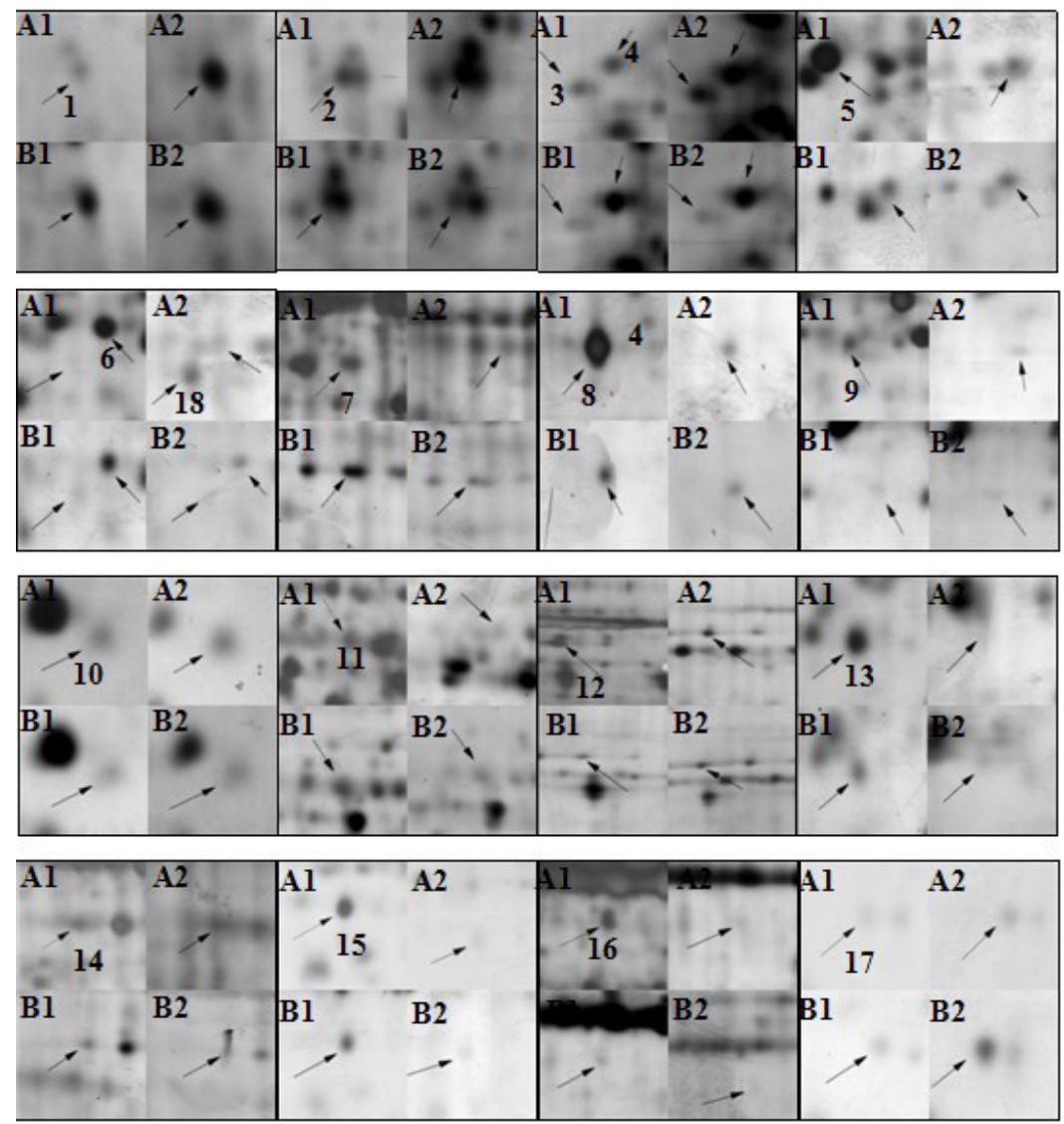

Figure 4. Partially magnified figures of identified proteins extracted from pistillate (A) and staminate (B) inflorescences when florets were at the hermaphroditic stage (Stage 1) and the unisexual stage (Stage 2), respectively.

Table 2. Differentially expressed proteins from buffalograss inflorescences.
\begin{tabular}{|cccccccc}
\hline Code & Mr (kDa) & $\mathrm{pI}$ & $\begin{array}{c}\text { Sequence } \\
\text { coverage }\end{array}$ & $\begin{array}{c}\text { Mascot } \\
\text { score }\end{array}$ & Accession No. & $\begin{array}{c}\text { Putative function/ } \\
\text { description }\end{array}$ & $\begin{array}{c}\text { Source } \\
\text { species }\end{array}$ \\
\hline 9 & 38.6 & 7.52 & $34 \%$ & 196 & gi|162462282 & $\begin{array}{c}\text { aldolase } 1 \\
\text { Os05g0574400 }\end{array}$ & Zea mays \\
15 & 35.4 & 8.22 & $22 \%$ & 123 & gi|115465579 & (similar to malate dehydrogenase) & Oryza sativa \\
\hline
\end{tabular}

For abbreviations, see Figure 2.

The genetic factors controlling floral sex differentiation in buffalograss have been reported before. Chandra and Huff (2010) reported that the female-suppressor gene $B d T s$, with its high expression level in male inflorescences, led to the selective abortion of the gynoecium and the development of unisexual male flowers. This study reported for the first time the 2-D electrophoresis protein maps of buffalograss inflorescences. The present study demonstrated that 2 sex-linked protein spots, which were present at one developmental stage and absent or drastically reduced in intensity at the other developmental stage, play important roles in floret 
differentiation. All the spots were analyzed twice by MALDI-TOF/TOF. This report possibly presents the first systematic proteomic analysis of floret differentiation in buffalograss. However, very few protein spots matched with the databases. One of the possible reasons for this could be that the proteins were extracted in quantities too small for accurate analysis. The inflorescences of buffalograss are just too tiny to collect samples that are sufficiently large for proteome analysis. In addition, the lack of identification may also be attributed to the protein database being incomplete and deficient zymohydrolysis. This suggests that the mass spectrum technique and the information content of databases are still the main constraining factors for this kind of research. The exact function of the differentially expressed proteins, which have a close correlation with sex differentiation, needs further studies.

\section{ACKNOWLEDGMENTS}

Research supported by the National Natural Science Foundation of China (\#30800799) and the Beijing Key Laboratory of Grassland Science.

\section{REFERENCES}

Andon NL, Hollingworth S, Koller A, Greenland AJ, et al. (2002). Proteomic characterization of wheat amyloplasts using identification of proteins by tandem mass spectrometry. Proteomics 2: 1156-1168.

Beetle AA (1950). Buffalograss-Native of the Shortgrass Plains. Agricultural Experiment Station. University of Wyoming, Laramie, 1-31.

Blum H, Beier H and Gross HJ (1987). Improved silver staining of plant proteins, RNA and DNA in polyacrylamide gels. Electrophoresis 8: 93-99.

Bracale M, Galli MG, Falavigna A and Soave C (1990). Sexual differentiation in Asparagus officinalis L. II. Total and newly synthesized proteins in male and female flowers. Sex. Plant Reprod. 3: 23-30.

Budak H, Shearman RC, Parmaksiz I, Gaussoin RE, et al. (2004). Molecular characterization of Buffalograss germplasm using sequence-related amplified polymorphism markers. Theor. Appl. Genet. 108: 328-334.

Campo S, Carrascal M, Coca M, Abian J, et al. (2004). The defense response of germinating maize embryos against fungal infection: a proteomics approach. Proteomics 4: 383-396.

Chandra A and Huff DR (2010). A fungal parasite regulates a putative female-suppressor gene homologous to maize tasselseed2 and causes induced hermaphroditism in male buffalograss. Mol. Plant Microbe Interact. 23: 239-250.

Dafny-Yelin M, Guterman I, Menda N, Ovadis M, et al. (2005). Flower proteome: changes in protein spectrum during the advanced stages of rose petal development. Planta 222: 37-46.

de Jong F, Mathesius U, Imin N and Rolfe BG (2007). A proteome study of the proliferation of cultured Medicago truncatula protoplasts. Proteomics 7: 722-736.

Farley AR and Link AJ (2009). Identification and quantification of protein posttranslational modifications. Methods Enzymol. 463: 725-763.

Gallardo K, Job C, Groot SP, Puype M, et al. (2002). Importance of methionine biosynthesis for Arabidopsis seed germination and seedling growth. Physiol. Plant 116: 238-247.

Golan-Goldhirsh A, Peri I, Birk Y and Smirnoff P (1998). Inflorescence bud proteins of Pistacia vera. Trees 12: 415-419.

Hou YN (2005). Study of Cytomorphology and Special Proteins on Sex Differentiation in Gymnoecladus Dioicus (L.) K. Koch. Master's thesis, Beijing Forest University, Beijing.

Huff DR and Wu L (1987). Sex expression in buffalograss under different environments. Crop Sci. 27: 623-626.

Imin N, Kerim T, Weinman JJ and Rolfe BG (2001). Characterisation of rice anther proteins expressed at the young microspore stage. Proteomics 1: 1149-1161.

Incamps A, Hely-Joly F, Chagvardieff P, Rambourg JC, et al. (2005). Industrial process proteomics: alfalfa protein patterns during wet fractionation processing. Biotechnol. Bioeng. 91: 447-459.

Irish EE and Nelson TM (1993). Development of TASSEL SEED 2 inflorescence in maize. Am. J. Bot. 80: 292-299.

Jindal KK and Singh RN (1976). Electrophoretic changes in soluble proteins during vegetative and floral development of male and female papaya plants. Biochem. Physiol. Pflanzen. 17: 80-85. 
Kinney MS, Columbus JT and Friar EA (2008). Unisexual flower, spikelet, and inflorescence development in monoecious/ dioecious Bouteloua dimorpha (Poaceae, Chloridoideae). Am. J. Bot. 95: 123-132.

Mathesius U, Keijzers G, Natera SH, Weinman JJ, et al. (2001). Establishment of a root proteome reference map for the model legume Medicago truncatula using the expressed sequence tag database for peptide mass fingerprinting. Proteomics 1: 1424-1440.

Mitchell CH and Diggle PK (2005). The evolution of unisexual flowers: morphological and functional convergence results from diverse developmental transitions. Am. J. Bot. 92: 1068-1076.

O'Farrell PH (1975). High resolution two-dimensional electrophoresis of proteins. J. Biol. Chem. 250: 4007-4021.

Rossignol M (2004). Proteomic investigation of natural variation between Arabidopsis ecotypes. Proteomics 4: 1372-1381.

van Wijk KJ (2001). Challenges and prospects of plant proteomics. Plant Physiol. 126: 501-508.

Wang QM and Zeng GW (1998). Study of specific protein on sex differentiation of Momordica charantia. Acta Bot. Sin. 14: 241-246.

Yergey AL, Coorssen JR, Backlund PS, Jr., Blank PS, et al. (2002). De novo sequencing of peptides using MALDI/TOFTOF. J. Am. Soc. Mass Spectrom. 13: 784-791.

Zhou YJ, Wang XG and Zhang XQ (2011). Development and Application of a SRAP Marker for the Identification of Sex in Buchloe dactyloides. Euphytica 181: 261-266.

Zivy M and de Vienne D (2000). Proteomics: a link between genomics, genetics and physiology. Plant Mol. Biol. 44: 575-580. 